JPdK Volume 3 Nomor 2 Tahun 2021 Halaman 106-116

JURNAL PENDIDIKAN dan KONSELING

Research \& Learning in Primary Education

\title{
Analisis Permasalahan Kesulitan Siswa Kelas VII SMP Dalam Menyelesaikan Masalah Terkait Materi Operasi Aljabar
}

\section{Tita Arsfenti ${ }^{1}$, Anggi Eka Wardani ${ }^{2}$, Dinda Nursetiya Putri ${ }^{3}$, Dania Februana ${ }^{4}$, Darmadi ${ }^{5}$}

\author{
Program Studi Pendidikan Matematika \\ Fakultas Keguruan dan Ilmu Pendidikan \\ Universitas PGRI Madiun \\ Email : titaarsfenti450@gmail.com, dindanursetiyaputri@gmail.com, anggiekaw09@ gmail.com, \\ daniafeb55@gmail.com, darmaixmadiun@gmail.com
}

\begin{abstract}
Abstrak
Aljabar merupakan subjek yang sangat penting dalam pembelajaran matematika. Oleh karena itu, siswa khususnya pada tingkat SMP kelas VII harus dapat memahami konsep ini dengan baik. Penelitian ini bertujuan untuk mendeskripsikan miskonsepsi siswa kelas VII dalam menyelesaikan permasalahan yang berkaitan dengan operasi bentuk aljabar. Metode penelitian yang digunakan dalam penelitian ini adalah penelitian deskriptif kualitatif. Subjek penelitian ini yaitu siswa kelas VII SMP. Instrumen pada penelitian ini berupa sebuah tes yang terdiri dari 10 soal tentang operasi bentuk aljabar. Hasil penelitian menunjukkan bahwa siswa melakukan beberapa kesalahan dalam menyelesaikan permasalahan tentang operasi bentuk aljabar, seperti kesalahan pada variabel, kesalahan pada tanda negatif, kesalahan pada menyelesaikan bentuk persamaan aljabar, kesalahan pada pengoperasian bentuk aljabar, dan kesalahan dalam penyelesaian bentuk pecahan.
\end{abstract}

Kata Kunci: Kesalahan Siswa, Aljabar, Deskriptif Kualitatif

\begin{abstract}
Algebra is a very important subject in mathematics learning. Therefore, students especially at seventhgrademust be able to understand this concept well. This study aims to explore information and describe students' errors in solving algebraic problems. The research method in this study uses qualitative descriptive. The subjects of this study were 36 seventh-grade students of SMP. The instrument in this study is a test consisting of 10 questions about the operation of algebraic forms. The results showed that students still made some mistakes in solving algebraic problems, such as errors in the variable, errors in negative signs, errors in completing the form of algebraic equations, errors in the operation of the algebraicform, and errors in solving fractions.
\end{abstract}

Keywords: Students' Errors, Algebra, Qualitative Descriptive

\section{PENDAHULUAN}

Pada awal tahun 2020, seluruh negara di dunia digemparkan oleh penemuan virus jenis baru yang berasal dari Wuhan, Cina. Virus ini bernama Coronavirus (Covid-19) yang menyebar dengan sangat cepat ke seleruh dunia termasuk Indonesia. Pemerintah bertindak cepat untuk mengurangi penyebaran virus ini karena pasien terpapar Covid-19 setiap hari meningkat dengan pesat. Beberapa kegiatan tatap muka dan berkerumun dihentikan termasuk dalam dunia pendidikan. Kegiatan belajar mengajar yang biasa dilakukan di sekolahdihentikan dan di alihkan menjadi belajar daring dari rumah maing-masing. Selama pembelajaran daring yang dilakukan secara mendadak tanpa persiapan yang matang, sehingga para siswa dan wali murid membutuhkan waktu yang cukup lama untuk menyesuaikan keadaan.

Model pembelajaran sangat berpengaruh dalam meningkatkan semangat siswa. Model pembelajaran tentunya bukan hanya sekedar alat untuk menyampaikan materi, tetapi juga dapat memberikan dorongan dan minat belajar bagi siswa (Romala, 2021). Dengan demikian guru dituntut untuk lebih kreatif dan inovatif dalam menyampaikan materi kepada siswa. Beberapa platform digunakan untuk menunjang pembelajaran daring diantaranya, WhatsApp, Google Meet, Google form, Google Classroom, dan lain-lain. Tujuan diadakannya penelitian ini adalah untuk mengukur pemahaman siswa dalam menyelesaikan permasalahan terkait Operasi pada Aljabar supaya dapat menyelesaikannya dengan 


\section{METODOLOGI PENELITIAN}

Jenis penelitian ini adalah penelitian deskriptif. "Penelitian deskriptif adalah penelitian yang dimaksudkan untuk mengumpulkan informasi mengenai status suatu gejala yang ada, yaitu keadaan gejala menurut apa adanya pada saat penelitian dilakukan" (Arikunto, 1995:309). Dalam penelitian deskriptif ini digunakan pendekatan kualitatif dan kuantitatif.Penelitian dilakukan di MTs Negeri Jetis Ponorogo pada Semester Ganjil Tahun Pelajaran 2013/2014 terhitung selama dua bulan mulai 9 September sampai dengan 28 Oktober 2013.Sejumlah 28 siswa kelas VIID terlibat sebagai subjek penelitian yang mengikuti tes tulis operasi pecahan aljabar, dimana 5 diantaranya ditentukan sebagai sampel penelitian (SP) yang akan dilibatkan dalam proses wawancara. Wawancara terhadap kelima sampel penelitian dilakukan sebagai bentuk klarifikasi atas kesalahan yang dilakukan sekaligus untuk mengungkap faktor-faktor penyebab kesalahannya. Penentuan kelima sampel penelitian dilakukan dengan teknik purposive sampling yaitu penentuan sampel yang didasarkan pada pertimbangan-pertimbangan tertentu.Selain siswa sebagai sumber data dalam penelitian ini, guru bidang studi matematika yang mengajar di kelas VIID juga termasuk sebagai sumber data karena turut berperan memberikan informasi-informasi yang diperlukan peneliti selama proses penelitian. Instrumen yang digunakan dalam penelitian ini diklasifikasikan menjadi dua kategori, yaitu:

1. Instrumen Utama

Sebagaimana diungkapkan Sugiyono (2009:306), peneliti merupakan instrumen utama. Kedudukan peneliti sebagai instrumen utama adalah sebagai perencana, pelaksana pengumpulan data, analisis, penafsir data dan pada akhirnya peneliti menjadi pelapor hasil penelitian (Moleong, 2006:168).

2. Instrumen Pendukung

Instrumen pendukung yang diperlukan antara lain sebagai berikut:

a. Soal Tes

Soal tes disusun dalam bentuk uraian (essay examination) sebanyak 10 butir soal, sedangkan kunci jawaban dibuat berdasarkan langkah-langkah penyelesaian soal. Untuk menentukan validitas instrumen dilakukan dengan pertimbangan validator (expert judgement), yaitu meng-konsultasikan soal tes yang telah disusun peneliti
Penyusunan soal disesuaikan dengan indikator yang telahditetapkan yaitu menghitung penjumlahan, pengurangan, perkalian, pembagian dan pemangkatan pecahan aljabar.

b. Pedoman Wawancara

Wawancara dilakukan terhadap kelima sampel penelitian. Melihat beragamnya jenis kesalahan dan kemungkinan luasnya jawaban yang akan diberikan siswa, maka jenis wawancara yang diterapkan dalam penelitian ini adalah wawancara bebas tidak terstruktur dimana pewawancara dapat menanyakan apa saja dengan tetap mengingat data apa yang akan dikumpulkan (Arikunto,2010:199). Agar tidak ada informasi yang terlewatkan dan hasil wawancara dapat terekam dengan baik maka digunakan alat bantu perekam (tape recorder) untuk merekam hasil wawancara (Sugiyono, 2009:195).

Teknik pengumpulan data dilakukan dengan berbagai metode antara lain sebagai berikut:

a. Metode Tes

b. Metode tes adalah cara pengumpulan data dengan memberikan sejumlah pertanyaan kepada siswa yang berkaitan dengan tujuan penelitian. Secara umum pelaksanaan tes operasi pecahan aljabar dilakukan sesuai prosedur berikut:

c. Metode Wawancara

Metode wawancara adalah cara pengumpulan data yang dilakukan melalui percakapan antara peneliti dengan sampel penelitian. Secara umum prosedur wawancara dalam penelitian ini dilakukan sebagai berikut:

1. Menetapkan kepada siapa wawancara akan dilakukan

2. Menyiapkan pokok-pokok masalah yang akan menjadi bahan pembicaraan

3. Mempersiapkan alat bantu wawancara

4. Mengawali alur wawancara

5. Melangsungkan alur wawancara

6. Mengkonfirmasikan hasil wawancara Mengidentifikasi tindak lanjut hasil wawancara yang telah diperoleh

d. Metode Dokumentasi 
Melalui metode dokumentasi peneliti mengumpulkan data-data tertulis yang diperlukan dalam penelitian ini antara lain daftar nama siswa kelas VIID dan bukubuku pelajaran matematika yang digunakan. Selain dokumen tertulis, peneliti juga mengumpulkan dokumen berupa foto-foto selama proses penelitian.

Dalam penelitian ini, analisis data dilakukan dengan mengacu konsep Miles dan Huberman. Adapun langkah-langkah analisis data diuraikan sebagai berikut:

\section{a. Reduksi Data}

Proses reduksi data pada hasil tes tulis dilakukan dengan mengoreksi setiap jawaban siswa. Kategori jawaban siswa yang terpilih sebagai sampel penelitian (SP) salah satunya didasarkan pada jenis kesalahan yang dominan dilakukan siswa serta dapat mewakili dari sekian banyak kesalahan yang terjadi. Proses reduksi data pada hasil wawancara dilakukan dengan mendengarkan rekaman hasil wawancara peneliti dengan sampel penelitian(SP). Selanjutnya men-transkrip rekaman tersebut dalam bentuk kutipan wawancara yang disusun dalam bentuk bahasa yang baik. Informasi yang diperoleh dari hasil wawancara ini sekaligus dapat memperkuat data hasil tes tulis dengan adanya klarifikasi dari siswa atas kesalahan yang dilakukan.

b. Penyajian Data

Hasil analisis data disajikan dengan mendeskripsikan jenis kesalahan dan faktor penyebab kesalahan siswa disertai dengan bukti jenis kesalahan yang dilakukan. Semua teknik penyajian data diatas dirancang dalam rangka untuk menggabungkan informasi yang tersusun menjadi suatu bentuk yang sistematis dan mudah dipahami.

c. Penarikan Kesimpulan

Penarikan kesimpulan dan verifikasi, yaitu proses memberikan kesimpulan dan memeriksa kebenaran data guna menjawab rumusan masalah dalam penelitian. Dari penyajian data yang telah disusun peneliti, apabila didukung oleh bukti-bukti yang valid dan konsisten maka peneliti dapat memanfaatkan data tersebut untuk penarikan kesimpulan.

Keabsahan data hasil suatu penelitian, apabila memenuhi validitas dan reliabilitas data. Berdasarkan hal itu, maka kriteria keabsahan data yang diperhatikan dalam penelitian ini adalah validitas dan reliabilitas data.

\section{HASIL PENELITIAN DAN PEMBAHASAN}

Uji z digunakan untuk menguji apakah kemampuan berpikir aljabar siswa yang mengikuti pembelajaran dengan model pembelajaran Learning Cycle 5E mencapai ketuntasan klasikal sekurang-kurangnya $70 \%$ dari peserta tes mencapai KKM individual, yaitu 70 .

Untuk uji proporsi, hipotesis yang diujikan adalah sebagai berikut. $H 0: \pi \leq$ 0.695 (kemampuan berpikir aljabar siswa kelas VII dalam model pembelajaran Learning Cycle 5E belum mencapai ketuntasan klasikal) $H 1 \quad: \quad \pi>0.695$ (kemampuan berpikir aljabar siswa kelas VII dalam model pembelajaran Learning Cycle 5E telah mencapai ketuntasan klasikal)

Kriteria pengujiannya adalah $\mathrm{H} 0$ ditolak jika $Z_{\text {hitung }} \geq z(0,5-\alpha)$, dimana $z(0,5-\alpha)$ didapat dari distribusi normal baku dengan peluang (0,5 $-\alpha)$ dengan $\alpha=5 \%$. (Sudjana, 2005: 234). Berdasarkan hasil perhitungan diperoleh $Z_{\text {hitung }}=1,75$ dan ztabel $=1,64$ dengan $\alpha=5 \%$. Karena $Z_{\text {hitung }} \geq Z_{\text {tabel, }}$, maka $H O$ ditolak. Artinya, kemampuan berpikir aljabar siswa kelas VIIdalam model pembelajaran Learning Cycle 5E klasikal telah mencapai ketuntasan klasikal. Berdasarkan hasil tes kemampuan berpikir aljabar juga dapat diketahui yaitu sebanyak 
30 dari 36 siswa telah mencapai KKM individual. Artinya, kemampuan berpikir aljabar siswa dalam model pembelajaran Learning Cycle 5E mencapai ketuntasan secara klasikal sebesar 83,33\%

Setelah dilakukan analisis data hasil tes berpikir aljabar, wawancara, dan triangulasi masing-masing subjek yang termasuk kelompok tingkat tinggi, tingkat sedang, dan tingkat rendah, diperoleh data sebagaimana ditampilkan pada Tabel 2 berikut.

Tabel 2. Hasil Analisis Tes Kemampuan Berpikir Aljabar

\begin{tabular}{|c|c|c|c|c|}
\hline $\begin{array}{c}\text { Kelompok } \\
\text { Berpikir } \\
\text { Aljabar }\end{array}$ & Subjek & \multicolumn{3}{|c|}{ Kemampuan dalam Berpikir Aljabar } \\
\cline { 3 - 5 } & & Generasional & Transformasional & $\begin{array}{c}\text { Meta } \\
\text { Global }\end{array}$ \\
\hline $\begin{array}{c}\text { Tingkat } \\
\text { Tinggi }\end{array}$ & T-1 & Tinggi & Tinggi & Tinggi \\
\cline { 2 - 5 } & T-2 & Tinggi & Tinggi & Tinggi \\
\hline & T-3 & Tinggi & Tinggi & Tinggi \\
\hline $\begin{array}{c}\text { Tingkat } \\
\text { Sedang }\end{array}$ & S-1 & Tinggi & Tinggi & Sedang \\
\hline & S-2 & Tinggi & Tinggi & Sedang \\
\hline & S-3 & Tinggi & Tinggi & Sedang \\
\hline $\begin{array}{c}\text { Tingkat } \\
\text { Rendah }\end{array}$ & R-1 & Tinggi & Tinggi & Rendah \\
\hline & R-2 & Sedang & Sedang & Rendah \\
\hline \hline & R-3 & Sedang & Sedang & Rendah \\
\hline
\end{tabular}

Dari Tabel 2 terlihat bahwa siswa cenderung lebih baik dalam aktivitas generasional dan transformasional baru kemudian aktivitas meta global.

Berdasarkan hasil analisis data tes kemampuan berpikir aljabar siswa pada materi segiempat dan segitiga diperoleh bahwa kelas sampel berdistribusi normal. Berdasarkan hasil tes kemampuan berpikir aljabar juga dapat diketahui bahwa sekurangkurangnya $70 \%$ dari peserta tes mencapai KKM individual 70 , yaitu sebanyak 30 dari 36 siswa telah mencapai KKM individual. Artinya, kemampuan berpikir aljabar siswa dalam model pembelajaran Learning Cycle 5E mencapai ketuntasan secara klasikal sebesar $83,33 \%$. Hasil ini sejalan dengan penelitian yang dilakukan oleh Eka Cahya Lestari dkk yang menunjukan bahwa kemampuan pemecahan masalah yang dikenai model pembelajaran Learning Cycle 5E telah mencapai ketuntasan klasikal sebesar $80,56 \%$. Selain itu, hasil ini juga sejalan dengan penelitian yang dilakukan oleh Ayin Ria Yufita yang menunjukkan bahwa penerapan Learning Cycle 5E mencapai ketuntasan klasikal sebesar $92,8 \%$

Pembahasan analisis kemampuan berpikir aljabar siswa yang termasuk kelompok kemampuan tinggi, sedang, dan rendah adalah sebagai berikut.

Pada kelompok tingkat tinggi, dalam aktivitas generasional, subjek kelompok tingkat tinggi mampu untuk menentukan makna variabel dari suatu masalah, dan merepresentasikan masalah dalam hubungan antar variabel. Hal tersebut dapat ditunjukkan dengan hasil tes dan wawancara subjek kelompok tingkat tinggi pada soal tes kemampuan aljabar nomor 1 , 2, 3, 4, 5, 6, dan 7 .

Pada soal nomor 1 ini, subjek kelompok tingkat tinggi yaitu T-1, T-2 dan T-3 mampu menuliskan kembali apa yang diketahui menggunakan variabel lain. Subjek T-1, T-2, dan T-3 dapat menuliskan makna dari persegi panjang yang mempunyai panjang $6 \mathrm{~cm}$ lebih besar dari lebarnya dan jika lebarnya adalah $l$ yaitu $p=$ $l+6 \mathrm{~cm}$. Subjek T-1, T-2, dan T-3 juga dapat menuliskan makna variabel dari unsur yang diketahui, hal tersebut salah satunya dapat ditunjukkan dengan hasil tes dan wawancara subjek kelompok tingkat tinggi pada soal tes kemampuan aljabar nomor 5 . Dari soal nomor 5 diketahui panjang sisi yang berdekatan adalah $3 x+2 \mathrm{~cm}$ dan $2 x+$ $2 \mathrm{~cm}$, tinggi jajargenjang $x+1 \mathrm{~cm}$. Keliling karton adalah $48 \mathrm{~cm}$, subjek T-1, T-2, dan T-3 dapat menuliskan ke dalam variabel yaitu $K=48 \mathrm{~cm}, a=3 x+2 \mathrm{~cm}, b=2 x+2$ $\mathrm{cm}, t=x+1 \mathrm{~cm}$.

Pada aktivitas transformasional, subjek-subjek kelompok tingkat tinggi menunjukkan kemampuan yang cenderung tinggi. Dalam mengerjakan soal-soal aljabar yang diberikan, subjek-subjek pada kelompok tingkat tinggi mampu untuk melakukan operasi bentuk aljabar, dan menentukan penyelesaian dari suatu persamaan dalam aljabar.

Hal tersebut salah satunya dapat ditunjukkan dengan hasil tes dan wawancara subjek kelompok tingkat tinggi pada soal tes kemampuan aljabar nomor 1, 2, 3, 4, 5, 6, dan 7. Pada soal nomor 3 ini, subjek kelompok tingkat tinggi yaitu T-1, T-2 dan T-3 mampu menuliskan rumus keliling persegi dan persegi panjang, melakukan operasi bentuk aljabar dengan hasil yang benar dari unsur yang diketahui yaitu sisi persegi $=s=(x+2) \mathrm{cm}$, panjang persegi panjang $=p=2 x-9 \mathrm{~cm}$, lebar persegi panjang $=l=x+1 \mathrm{~cm}$ lalu disubstitusikan $\mathrm{ke}$ persamaan Kpersegi= 
Kpersegipanjang serta dapat menentukan penyelesaian dari suatu persamaan dalam aljabar diperoleh $x=$ 12. Tetapi untuk nomor 5 , subjek T-3 tidak dapat menentukan penyelesaian dari suatu persamaan dalam aljabar yaitu memperoleh $x=10$.

Subjek-subjek pada kelompok tingkat tinggi juga menunjukkan kemampuan yang cenderung tinggi pada aktivitas meta global. Pada aktivitas meta global, subjek kelompok tingkat tinggi mampu menggunakan aljabar untuk menganalisis perubahan, hubungan, dan memprediksi suatu masalah dalam matematika, dan memodelkan masalah dan menyelesaikannya.

Hal tersebut dapat ditunjukkan dengan hasil tes dan wawancara subjek kelompok tingkat tinggi pada soal tes kemampuan aljabar nomor 2 dan 6, yang meminta siswa untuk dapat memodelkan masalah dan menyelesaikannya serta dapat menggunakan aljabar untuk menganalisis perubahan. Pada soal nomor 2 diketahui perbandingan panjang dan lebarnya $8: 4$, subjek T-1, T-2, dan T-3 memisalkan panjang dan lebar sehingga $p=8 x$ dan $l=4 x$.

Pada soal nomor 6 ini, subjek kelompok tingkat $\mathrm{t}$ inggi yaitu $\mathrm{T}-1$, $\mathrm{T}-2$ dan T-3 mampu menggunakan aljabar untuk menganalisis perubahan keliling dan luas belahketupat jika sisi sisinya menjadi 5 kali panjang sisi semula dan diagonaldiagonalnyadiperbesar menjadi 3 kali semula, bahwa keliling belahketupat berubah menjadi 5 kali keliling semula, sedangkan luasnya berubah menjadi 9 kali luas semula. Subjek T-1, T-2, dan T-3 menjawab soal nomor 6 ini dengan mencari keliling dan luas belahketupat tersebut sebelum dan sesudah panjang sisi dan diagonalnya bertambah, kemudian membandingkannya

P : Untuk nomor 1, apakah soal nomor 1 bisa dipahami?

T-1 : Bisa bu.

$\mathrm{P}$ : Apa yang diketahui dari soal nomor $1 ?$

T-1 : Yang diketahui $p=(l+6) \mathrm{cm}$, sedangkan $l=l \mathrm{~cm}$

$\mathrm{P}$ : Diperoleh darimana?

T-1 : Kan diketahui persegi panjang mempunyai panjang $6 \mathrm{cmlebih}$ besar dari lebarnya $\mathrm{lcm}$ maka panjangnya $p=(l+$ 6) $\mathrm{cm}$

P : Untuk nomor 2, apakah soal nomor 2 bisa dipahami?
T-1 : Bisa bu. P : Apa yang diketahui dari soal nomor 2 ?

T-1 : Diketahui keliling $K=240 m, p=$ $8 x \mathrm{~cm}$ dan $l=4 x \mathrm{~m}$.

$\mathrm{P}$ : Diperoleh darimana $p=8 x \mathrm{~m}$ dan $l=$ $4 x m$ ?

$\mathrm{T}-1$ : Kan perbandingan panjang dibanding lebar $p: l=8: 4$

$\mathrm{P}$ : Untuk nomor 7, apakah soal bias dipahami? T-1 : Bisa bu.

$\mathrm{P}$ : Apa yang diketahui dari soal nomor 7 ?

$\mathrm{T}-1$ : Yang diketahui $d 1=3 x \mathrm{~cm}, d 2=$ $2 x \mathrm{~cm}, L=108 \mathrm{~cm} 2$

Gambar 1. Hasil Wawancara Subjek T-1 untuk Soal Generasional

P : Untuk nomor 3, apa yang ditanyakan?

$\mathrm{T}-1$ : Panjang sisi persegi bu

$\mathrm{P}$ : Gimana cara mengerjakannya?

T-1 : Kan diketahui keliling persegi samadengan keliling persegi panjang, berarti $4 \times s=2(p+l) \mathrm{P}:$ Terus? T-1 $: s=x+2$ $\mathrm{cm}, p=2 x-9 \mathrm{~cm}, l=x+1 \mathrm{~cm}$, terus tinggal substistusi $4 \times x+2=22 x-9+x+$ 1

$\mathrm{P}$ : Berapa $x$ yang diperoleh?

$\mathrm{T}-1: x$ nya 12 bu $\mathrm{P}$ : Untuk nomor 4 , apakah soal nomor 4 bisa dipahami?

$\mathrm{T}-1$ : Bisa bu. P : Gimana cara mengerjakannya?

T-1 : Ya kan diketahui keliling taman yang berbentuk persegi $K=120 \mathrm{~m}$, sisinya $x \mathrm{~m}$.

Nah berarti kan $4 \times x=120$ terus ketemu deh $x$-nya 30

$\mathrm{P}$ : Oh gitu, nah terus yang ditanyain apa?

T-1 : Luas taman, ya tinggal mengalikan.

Kan rumus luas itu $L=s \times s=30 \times 30=$ $900 \mathrm{~cm} 2 \mathrm{P}$ : Untuk nomor 5, apakah soal bisa dipahami?

$\mathrm{T}-1$ : Bisa bu.

$\mathrm{P}$ : Terus gimana cara kamu mengerjakan soal nomor 5?

T-1 : Soanya kan tentang karton berbentuk jajargenjang, nah yang diketahui kan $K=48$ $c m, a=3 x+2 c m, b=2 x+2 c m, t=x+1$ $c m$. terus tinggal substitusi $K=2(a+b)$, sehingga $48=23 x+2+2 x+2$. Diperoleh $x=4$

$\mathrm{P}$ : Terus apa lagi? T-1 : Yang ditanyakan kan luas, nah luas jajargenjang itu $L=a \times t$, nah $a$-nya kan 14 terus $t$-nya 5 , jadi luasnya 70

$\mathrm{P}$ : Dapat 10 sama 5 darimana?

T-1 : Tinggal disubstitusi nilai $x$ ke alas dan tinggi bu.

Gambar 2 Hasil Wawancara Subjek T-1 


\section{untuk Soal Transformasional}

P : Untuk nomor 2, apakah soal nomor 2 bisa dipahami?

T-1 : Bisa bu. P : Gimana cara kamu mengerjakan?

T-1 : Kalau ngga salah si gini bu, kan yang diketahui keliling taman berbentuk persegi $K=240 \mathrm{~m}$, perbandingan panjang dan lebar $p: l=8: 4$. Nah karena cuma tau perbandingannya maka dimisalkan $x$ untuk memisalkan berapa kali dari perbandingan itu bu, jadi panjang $p=8 x \mathrm{~m}$ dan lebar $l=4 x \mathrm{~m}$

$\mathrm{P}$ : Lalu dari permisalanmu tadi berapa niai $x$ yang diperoleh? Berapa $p$ dan $l$ nya? T-1 : Nilai $x$-nya 4 bu. Karena $p=$ $8 x \mathrm{~m}$ maka $p=8 \times 4=32 \mathrm{mdan}$ untuk $l$ $=4 x \mathrm{~m}$ maka $l=4 \times 4=16 \mathrm{~m}$.

$\mathrm{P}$ : Untuk nomor 6 , apakah soal nomor 6 bisa dipahami?

$\mathrm{T}-1$ : Bisa bu

P : Apakah kamu bisa menjawabnya?

T-1 : Bisa bu, kelilingnya menjadi 5 kali keliling semula dan luasnya menjadi 9 kali luas semula P : Dapat dari mana?

T-1 : Ya kan kalau sisi belahketupat $s$ kalau diperbesar 5 kali menjadi $5 s$. Sehingga keliling baru $K=4 \times 5 s=5 \times$ $4 \times s=5$ kali keliling semula. Terus kalau diagonal belahketupat $d 1$ dan $d 2$ kalau diperbesar 3 kali menjadi $3 d 1$ dan $3 d 2$. Sehingga luas baru $L=3 d 1 \times 3 d 22=9 \times$ $d 1 \times d 22=9$ kali luas semula .

\section{Gambar 3 Hasil Wawancara Subjek}

T-1 untuk Soal Meta Global

Hal ini sejalan dengan penelitian yang dilakukan oleh Badawi et al yang menunjukkan bahwa aktivitas generasional, transformasional, dan meta global pada kelompok tingkat tinggi cenderung tinggi semua. Pada aktivitas generasional, subjek kelompok tingkat tinggi mampu untuk memahami generalisasi yang muncul dari pola geometri, menentukan makna variabel dari suatu masalah, dan merepresentasikan masalah dalam hubungan antar variabel. Pada aktivitas tranformasional dalam mengerjakan soalsoal aljabar yang diberikan, subjeksubjek pada kelompok tingkat tinggi mampu menentukan bentuk aljabar yang ekivalen dan menentukan penyelesaian dari suatu persamaan dalam aljabar. Pada aktivitas meta global, subjek kelompok tingkat tinggi mampu menggunakan aljabar untuk menganalisis perubahan, hubungan, dan memprediksi suatu masalah dalam matematika, serta menggunakan aljabar untuk memecahkan masalah yang berkaitan dengan bidang ilmu lain

Pada kelompok tingkat sedang, dalam aktivitas generasional, subjek kelompok tingkat sedang mampu untuk menentukan makna variabel dari suatu masalah, dan merepresentasikan masalah dalam hubungan antar variabel. Hal tersebut dapat ditunjukkan dengan hasil tes dan wawancara subjek kelompok tingkat sedang pada soal tes kemampuan aljabar nomor 1, 2, 3, 4, 5, 6, dan 7. Pada soal nomor 1 ini, subjek kelompok tingkat sedang yaitu $\mathrm{S}-1$, S-2 dan S-3 mampu menuliskan kembali apa yang diketahui menggunakan variabel lain. Subjek S-1, S-2, dan S-3 dapat menuliskan makna dari persegi panjang yang mempunyai panjang $6 \mathrm{~cm}$ lebih besar dari lebarnya dan jika lebarnya adalah $l$ yaitu $p=$ $l+6 \mathrm{~cm}$. Subjek T-1, T-2, dan T-3 juga dapat menuliskan makna variabel dari unsur yang diketahui, hal tersebut salah satunya dapat ditunjukkan dengan hasil tes dan wawancara subjek kelompok tingkat sedang pada soal tes kemampuan aljabar nomor 5 . Dari soal nomor 5 diketahui panjang sisi yang berdekatan adalah $3 x+2 \mathrm{~cm}$ dan $2 x+$ $2 \mathrm{~cm}$, tinggi jajargenjang $x+1 \mathrm{~cm}$. Keliling karton adalah $48 \mathrm{~cm}$, subjek T-1, T-2, dan T-3 dapat menuliskan ke dalam variabel yaitu $K=48 \mathrm{~cm}, a=3 x+2 \mathrm{~cm}, b$ $=2 x+2 \mathrm{~cm}, t=x+1 \mathrm{~cm}$.

Pada aktivitas transformasional, subjek-subjek kelompok tingkat sedang menunjukkan kemampuan yang cenderung tinggi. Dalam mengerjakan soal-soal aljabar yang diberikan, subjek-subjek pada tingkat sedang mampu untuk melakukan operasi bentuk aljabar, dan menentukan penyelesaian dari suatu persamaan dalam aljabar. Hal tersebut salah satunya dapat ditunjukkan dengan hasil tes dan wawancara subjek kelompok tingkat sedang pada soal tes kemampuan aljabar nomor 1, 2, 3, 4, 5, 6, dan 7

Pada soal nomor 3 ini, subjek kelompok tingkat sedang yaitu S-1, S-2 dan S-3 mampu menuliskan rumus keliling persegi dan persegi panjang, melakukan operasi bentuk aljabar dengan hasil yang 
benar dari unsur yang diketahui yaitu sisi persegi $=s=(x+2) \mathrm{cm}$,

panjang persegi panjang $=p=2 x$ $-9 \mathrm{~cm}$, lebar persegi panjang $=l=x+1$ $\mathrm{cm}$ lalu disubstitusikan ke persamaan Kpersegi $=$ Kpersegipanjang, serta dapat menentukan penyelesaian dari suatu persamaan dalam aljabar diperoleh $x=12$. Tetapi S-1, S-2 tidak mengerjakan nomor 6 dan S-3 tidak mengerjakan nomor 2, sehingga $\mathrm{S}-1, \mathrm{~S}-$ 2, dan S-3 tidak memenuhi indikator kemampuan transformasional nomor 2 dan 6.

Subjek-subjek pada kelompok tingkat sedang juga menunjukkan kemampuan yang cenderung sedang pada aktivitas meta global. Pada aktivitas meta global, subjek kelompoktingkat sedang mampu menggunakan aljabar untuk menganalisis perubahan, hubungan, dan memprediksi suatu masalah dalam matematika, dan memodelkan masalah dan menyelesaikannya. Hal tersebut dapat ditunjukkan dengan hasil tes dan wawancara subjek kelompok tingkat sedang pada soal tes kemampuan aljabar nomor 2 dan 6, yang meminta siswa untuk dapat memodelkan masalah dan menyelesaikannya serta dapat menggunakan aljabar untuk menganalisis perubahan. Pada soal nomor 2 diketahui perbandingan panjang dan lebarnya $8: 4$, subjek S-1 memisalkan panjang dan lebar sehingga $p=8 x$ dan $l=4 x$. Tetapi untuk subjek S-2 dan S-3 tidak mengerjakan nomor 6 sehingga tidak memenuhi indikator memodelkan masalah. Pada soal nomor 6 ini, subjek kelompok tingkat sedang yaitu S-1 tidak mampu menggunakan aljabar untuk menganalisis perubahan keliling dan luas belahketupat jika sisi sisinya menjadi 5 kali panjang sisi semula dan diagonaldiagonalnyadiperbesar menjadi 3 kali semula. Berbeda dengan S-2 dan S-3 yang dapat menganalisis perubahan keliling dan luas belahketupat tersebut, bahwa keliling belahketupat berubah menjadi 5 kali keliling semula, sedangkan luasnya berubah menjadi 9 kali luas semula.

Untuk aktivitas generasional dan meta global sejalan dengan penelitian yang dilakukan oleh Ahmad Badawi et al yang menunjukkan bahwa aktivitas generasional cenderung tinggi dan meta global cenderung sedang. Tetapi tidak sejalan pada aktivitas transformasional yaitu cenderung rendah sampai sedang. Pada aktivitas generasional,subjek kelompok tingkat sedang secara umum mampu untuk memahami generalisasi yang muncul dari pola geometri, memahami generalisasi yang muncul dari barisan bilangan, menentukan makna variabel dari suatu masalah, dan merepresentasikan masalah dalam hubungan antar variabel.

Pada aktivitas level-meta global, subjek kelompok tingkat sedang yang mampu memenuhi salah satu atau beberapa indikator dari aktivitas levelmeta global yang terdiri dari menggunakan aljabar untuk menganalisis perubahan, hubungan, dan memprediksi suatu masalah dalam matematika, menggunakan aljabar untuk memodelkan masalah serta menyelesaikannya, serta menggunakan aljabar untuk memecahkan masalah yang berkaitan dengan bidang ilmu lain. Pada aktivitas tranformasional sedikit berbeda, yaitu subjek-subjek pada kelompok tingkat sedang mampu menentukan penyelesaian dari suatu persamaan dalam aljabar, namun masih salah ketika melakukan operasi bentuk aljabar dan menentukan bentuk aljabar yang ekivalen.

$\mathrm{P}$ : Untuk nomor 1, apakah soal nomor 1 bisa dipahami? S-1 : Bisa bu.

$\mathrm{P}$ : Apa yang diketahui dari soal nomor 1 ? S-1 : Yang diketahui $p=(l+6) \mathrm{cm}$, sedangkan $l=l \mathrm{~cm}$

$\mathrm{P}$ : Diperoleh darimana?

S-1 : Kan diketahui persegi panjang mempunyai panjang $6 \mathrm{~cm}$ lebih besar dari lebarnya $l \mathrm{~cm}$ maka panjangnya $p=(l+6)$ $\mathrm{cm}$

P : Untuk nomor 2, apakah soal nomor 2 bisa dipahami?

S-1 : Bisa bu. P : Apa yang diketahui dari soal nomor 2?

S-1 : Diketahui keliling $K=240 m, p=$ $8 x \mathrm{~cm}$ dan $l=4 x \mathrm{~m}$.

$\mathrm{P}$ : Diperoleh darimana $p=8 x \mathrm{mdan} l=$ $4 x m$ ?

S-1 : Kan perbandingan panjang dibanding lebarp: $l=8: 4 \mathrm{P}:$ Untuk nomor 7, apakah soal bias dipahami? 
S-1 : Bisa bu.

$\mathrm{P}$ : Apa yang diketahui dari soal nomor $7 ?$

S-1 : Yang diketahui $d 1=3 x \mathrm{~cm}, d 2=$ $2 x \mathrm{~cm}, L=108 \mathrm{~cm} 2$

Gambar 4 Hasil Wawancara Subjek S1 untuk Soal Generasional

P : Untuk nomor 3, apa yang ditanyakan?

S-1 : Panjang sisi persegi bu.

$\mathrm{P}$ : Gimana cara mengerjakannya?

S-1 : Kan diketahui keliling persegi samadengan keliling persegi panjang, berarti $4 \times s=2(p+l) \mathrm{P}:$ Terus?

S-1 $: s=x+2 \mathrm{~cm}, p=2 x-9 \mathrm{~cm}, l=x$ $+1 \mathrm{~cm}$, terus tinggal substistusi $4 \times x+2$ $=22 x-9+x+1 \mathrm{P}$ : Berapa $x$ yang diperoleh?

S-1 : $x$ nya 12 bu

$\mathrm{P}$ : Untuk nomor 4 , apakah soal nomor 4 bisa dipahami?

S-1 : Bisa bu

$\mathrm{P}$ : Gimana cara mengerjakannya?

S-1 : Ya kan diketahui keliling taman yang berbentuk persegi $K=120 \mathrm{~m}$, sisinya $x m$. Nah berarti kan $4 \times x=120$ terus ketemu deh $x$-nya 30

$\mathrm{P}$ : Oh gitu, nah terus yang ditanyain apa? S-1 : Luas taman, ya tinggal mengalikan. Kan rumus luas itu $L=s \times s=30 \times 30=$ $900 \mathrm{~cm} 2 \mathrm{P}$ : Untuk nomor 5, apakah soal bias dipahami?

S-1 : Bisa bu.

$\mathrm{P}$ : Terus gimana cara kamu mengerjakan soal nomor 5 ?

S-1 : Soanya kan tentang karton berbentuk jajargenjang,nah yang diketahui kan $K=48 \mathrm{~cm}, a=3 x+2$ $c m, b=2 x+2 \mathrm{~cm}, t=x+1 \mathrm{~cm}$. terus tinggal substitusi $K=2(a+b)$, sehingga $48=23 x+2+2 x+2$. Diperoleh $x=4$ $\mathrm{P}:$ Terus apa lagi?

S-1 : Yang ditanyakan kan luas, nah luas jajargenjang itu $L=a \times t$, nah $a$-nya kan 14 terus $t$-nya 5 , jadi luasnya $70 \mathrm{P}$ : Dapat 10 sama 5 darimana?

S-1 : Tinggal disubstitusi nilai $x$ ke alas dan tinggi bu

Gambar 5 Hasil Wawancara Subjek S1 untuk Soal Transformasional

P : Untuk nomor 2, apakah soal nomor 2 bisa dipahami?

T-1 : Bisa bu. P : Gimana cara kamu mengerjakan?

T-1 : Kalau ngga salah si gini bu, kan yang diketahui keliling taman berbentuk persegi $K=240 \mathrm{~m}$, perbandingan panjang dan lebar $p: l=8: 4$. Nah karena cuma tau perbandingannya maka dimisalkan $x$ untuk memisalkan berapa kali dari perbandingan itu bu, jadi panjang $p=8 x \mathrm{~m}$ dan lebar $l=$ $4 x m$.

$\mathrm{P}$ : Lalu dari permisalanmu tadi berapa niai $x$ yang diperoleh? Berapa $p$ dan $l$-nya?

T-1 : Nilai $x$-nya 4 bu. Karena $p=8 x m$ maka $p=8 \times 4=32 \mathrm{~m}$ dan untuk $l=$ $4 x m$ maka $l=4 \times 4=16 \mathrm{~m}$.

$\mathrm{P}$ : Untuk nomor 6, apakah soal nomor 6 bisa dipahami?

T-1 : Kurang paham bu. P : Apakah kamu bisa menjawabnya?

T-1 : Tidak bisa bu, karena saya bingung bagaimana cara menjawabnya. Jadi saya mengarang saja.

\section{Gambar 6 Hasil Wawancara Subjek T-1} untuk Soal Meta Global

Pada kelompok tingkat rendah, dalam aktivitas generasional, subjek kelompok tingkat rendah mampu untuk menentukan makna variabel dari suatu masalah, dan merepresentasikan masalah dalam hubungan antar variabel. Hal tersebut dapat ditunjukkan dengan hasil tes dan wawancara subjek kelompok tingkat rendah pada soal tes kemampuan aljabar nomor 1, 2, 3, 4, 5, 6, dan 7. Pada soal nomor 1 ini, subjek kelompok tingkat rendah yaitu R-1 mampu menuliskan kembali apa yang diketahui menggunakan variabel lain. Subjek R-1 dapat menuliskan makna dari persegi panjang yang mempunyai panjang 6 $\mathrm{cm}$ lebih besar dari lebarnya dan jika lebarnya adalah $l$ yaitu $p=(l+6) \mathrm{cm}$. Tetapi R-2 dan R-3 tidak mampu menuliskan kembali apa yang diketahui menggunakan variabel lain. Subjek R-2, dan R-3 tidak dapat menuliskan makna dari persegi panjang yang mempunyai panjang 6 $\mathrm{cm}$ lebih besar dari lebarnya dan jika lebarnya adalah $l$ maka nilai $p=6 \mathrm{~cm}$. Subjek R-1, R-2, dan R-3 juga dapat menuliskan makna variabel dari unsur yang diketahui, hal tersebut salah satunya dapat ditunjukkan dengan hasil tes dan wawancara subjek kelompok tingkat rendah pada soal tes kemampuan aljabar nomor 5. Dari soal nomor 5 diketahui panjang sisi yang berdekatan adalah $3 x+2 \mathrm{~cm}$ dan $2 x+2 \mathrm{~cm}$, tinggi jajargenjang $x+1 \mathrm{~cm}$. Keliling karton adalah $48 \mathrm{~cm}$, subjek R-1, R-2, dan $\mathrm{R}-3$ dapat menuliskan kedalam 
variabelyaitu $K=48 \mathrm{~cm}, a=3 x+2 \mathrm{~cm}$ $, b=2 x+2 \mathrm{~cm}, t=x+1 \mathrm{~cm}$.

Pada aktivitas transformasional, subjek-subjek kelompok tingkat rendah menunjukkan kemampuan yang cenderung sedang. Dalam mengerjakan soal-soal aljabar yang diberikan, subjeksubjek pada kelompok tingkat rendah mampu untuk melakukan operasi bentuk aljabar, dan menentukan penyelesaian dari suatu persamaan dalam aljabar.

Hal tersebut salah satunya dapat ditunjukkan dengan hasil tes dan wawancara subjek kelompok tingkat rendah pada soal tes kemampuan aljabar nomor 1, 2, 3, 4, 5, 6, dan 7. Pada soal nomor 3 ini, subjek kelompok tingkat rendah yaitu R-1, R-2 dan R-3 mampu menuliskan rumus keliling persegi dan persegi panjang, melakukan operasi bentuk aljabar dengan hasil yang benar dari unsur yang diketahui yaitu sisi persegi $=s=(x+2) \mathrm{cm}$, panjang persegi panjang $=p=2 x-9 \mathrm{~cm}$, lebar persegi panjang $=l=x+1 \mathrm{~cm}$ lalu disubstitusikan ke persamaan Kpersegi = Kpersegipanjang, serta dapat menentukan penyelesaian dari suatu persamaan dalam aljabar diperoleh $x=$ 12. Tetapi R-1, R-2 tidak mengerjakan dengan benar nomor 1, 2, 6 dan S-3 tidak mengerjakan dengan benar nomor 1, 2, 5, 6, sehingga R-1, R-2, dan R-3 tidak memenuhi indikator kemampuan transformasional nomor 1, 2, 5 dan 6 .

Subjek-subjek pada kelompok tingkat rendah juga menunjukkan kemampuan yang cenderung rendah pada aktivitas meta global. Pada aktivitas meta global, subjek kelompok tingkat rendah mampu menggunakan aljabar untuk menganalisis perubahan, hubungan, dan memprediksi suatu masalah dalam matematika variabel, dan memodelkan masalah dan menyelesaikannya. Hal tersebut dapat ditunjukkan dengan hasil tes dan wawancara subjek kelompok tingkat rendah pada soal tes kemampuan aljabar nomor 2 dan 6, yang meminta siswa untuk dapat memodelkan masalah dan menyelesaikannya serta dapat menggunakan aljabar untuk menganalisis perubahan. Pada soal nomor 2 diketahui perbandingan panjang dan lebarnya 8 : 4, subjek R-1 tidak mengerjakan secara lengkap hanya menulis apa yang diketahui, sedangkan R-2 dan R-3 tidak megerjakan soal nomor 2 , sehingga $\mathrm{R}$ 1, R-2, dan R-3 tidak memenuhi indikator memodelkan masalah. Pada soal nomor 6 ini, subjek kelompok tingkat rendah yaitu R1, R-2 dan R-3 tidak mampu menggunakan aljabar untuk menganalisis perubahan keliling dan luas belahketupat jika sisi sisinya menjadi 5 kali panjang sisi semula dan diagonal-diagonalnyadiperbesar menjadi 3 kali semula. Subjek R-1, R-2 dan R-3 tidak mampu mengerjakan nomor 6 dengan benar sampai akhir

Untuk kemampuan berpikir aljabar kelompok tingkat rendah terdapat banyak perbedaan dengan penelitian yang dilakukan oleh Ahmad Badawi et al penelitian tersebut menunjukkan bahwa pada aktivitas generasional cenderung rendah sampai sedang, aktivitas transformasional cenderung rendah, dan aktivitas meta global cenderung rendah sampai sedang. Pada aktivitas generasional, subjek kelompok tingkat rendahmampu memahami generalisasi yang muncul dari pola geometri. Namun, sebagian besar belum mampu untuk memahami generalisasi yang muncul dari barisan bilangan, menentukan makna variabel dari suatu masalah, dan merepresentasikan masalah dalam hubungan antar variabel.

Pada aktivitas tranformasional dalam mengerjakan soal-soal aljabar yang diberikan, subjek-subjek pada kelompok tingkat rendah cenderung belum mampu untuk menentukan bentuk aljabar yang ekivalen, melakukan operasi bentuk aljabar, dan menentukan penyelesaian dari suatu persamaan dalam aljabar. Pada aktivitas meta global, sebagian besar subjek kelompok tingkat rendah belum mampu menggunakan aljabar untuk menganalisis perubahan, hubungan, dan memprediksi suatu masalah dalam matematika, menggunakan aljabar untuk memodelkan masalah serta menyelesaikannya, serta menggunakan aljabar untuk memecahkan masalah yang berkaitan dengan bidang ilmu lain.

\section{SIMPULAN}

Berdasarkan hasil penelitian yang telah diuraikan sebelumnya ,maka dapat 
diambil kesimpulan sebagai berikut:

Jenis-jenis kesalahan siswa dalam melakukan operasi aljabar antara lain:

1. Kesalahan penerapan sifat operasi antar variabel

2. Kesalahan penerapan sifat perkalian distribusi

3. Kesalahan penafsiran kaidah pencoretan

4. Kesalahan tidak menggabungkan suku sejenis

5. Kesalahan tidak melakukan penyederhanaan pecahan

6. Kesalahan pemahaman konsep operasi aljabar

7. Kesalahan penerapan operasi hitung

8. Kesalahan tidak menerapkan perkalian silang

9. Kesalahan penulisan akibat kecerobohan

10. Kesalahan menghilangkan data pada langkah penyelesaian

Adapun saran yang dapat peneliti berikan kepada pihak-pihak yang terkait adalah sebagai berikut:

A. Guru

1. Materi dalam matematika saling berkaitan satu sama lain, untuk itu sebelum menyampaikan suatu materi hendaknya guru memastikan bahwa materi prasyarat telah dikuasai dengan baik oleh siswa sehingga dapat memudahkan guru menjelaskan materi selanjutnya.

2. Perlunya menganalisis hasil pekerjaan siswa untuk mengetahui kesalahan yang dilakukan dalam pemecahan persoalan, selanjutnya mengkomunikasikan kesalahan dengan siswa agar kesalahan serupa dapat dihindari.

B. Siswa

1. Siswa hendaknya tidak mencukupkan diri dengan pelajaran yang diberikan guru disekolah namun dapat meningkatkan intensitas belajar di rumah, aktif dalam kegiatan pembelajaran di kelas dan banyak melakukan latihan khususnya pemecahan persoalan pada matematika.

2. Mengkonsultasikan kepada guru terkait kesulitan belajar yang dialami sehingga guru dapat segera memberikan bantuan untuk mengatasi kesulitan belajar siswa.

3. Dalam melakukan pemecahan persoalan matematika, akan lebih baik jika siswa meningkatkan ketelitian pada setiap langkah penyelesaian soal sehingga dapat meminimalisir kesalahan-kesalahan yang terjadi.

C. Pihak Sekolah

1. Peneliti menyarankan kepada pihak sekolah hendaknya melengkapi fasilitas belajar di sekolah dan memberikan sosialisasi kepada siswa untuk meningkatkan belajar matamatika sehingga siswa terampil dalam melakukan pemecahan persoalan matematika.

2. Melakukan peningkatan kompetensi guru dengan menyelenggarakan pelatihan bagi guru yang difokuskan pada upaya-upaya mengatasi kesulitan belajar siswa.

D. Peneliti Lain

1. Peneliti lain yang akan melakukan penelitian sejenis disarankan melakukan uji coba terhadap soal tes yang akan diberikan kepada siswa kemudian melakukan perbandingan hasil tes dari peneliti dengan hasil tes dari guru. Tujuan melakukan perbandingan ini dimaksudkan untuk mengetahui tingkat kesukaran soal ketika terjadi perbedaan yang signifikan antara hasil tes dari peneliti dengan hasil tes dari guru sehingga dapat menjadi bahan pertimbangan peneliti dalam penyusunan soal tes.

Peneliti lain disarankan mengadakan penelitian pada materi selain aljabar untuk menemukan jenis-jenis kesalahan berikut faktor penyebab kesalahan siswa dalam melakukan pemecahan persoalan matematika atau dapat mengembangkan penelitian ini dengan indikator selain operasi pecahan aljabar.

\section{DAFTAR PUSTAKA}

Harianti, F. (2018). Pengaruh Model Pembelajaran Guided Discovery Learning terhadap Kemampuan Pemahaman dan Hasil Belajar Siswa Materi Operasi Aljabar Kelas VII SMP. Journal of Mathematic Education, Science and Technology, 82-91. 
Huzaimah, P. Z., \& Amelia, R. (2021). Hambatan yang Dialami Siswa Dalam Pembelajaran Daring Matematika Pada Masa Pandemi COVID-19. Jurnal Cendekia:Jurnal Pendidikan Matematika, 533-541.

Isrok'atun, \& Rosmala, A. (2018). Model-Model Pembelajaran Matematika. Jakarta: Bumi Aksara.

Januarvi, E. D. (2016). Kesulitan Siswa dalam Menyelesaikan Operasi Hitung Aljabar Bentuk Pecahan. 2016: eprints.uns.ac.id.

Malihatuddarojah, D., \& Prahmana, r. C. (2019). ANALISIS KESALAHAN SISWA DALAM MENYELESAIKAN

PERMASALAHAN OPERASI BENTUK ALJABAR. Jurnal Pendidikan Matematika, 1-8.

Marisa, G., Syaiful, \& Hariyadi, B. (2020). Analisis Kesalahan Siswa Dalam Menyelesaikan Soal Operasi Aljabar berdasarkan Taksonomi SOLO. Jurnal Pendidikan Matematika, 77-88.

Martono, N. (2014). METODE PENELITIAN KUANTITATIF Analisis Isi dan Analisis Data Sekunder. Depok: PT. RAJAGRAFINDO PERSADA.

Silma, u. (2018). ANALISIS KEMAMPUAN BERPIKIR ALJABAR SISWA DALAM MODEL PEMBELAJARAN LEARNING CYCLE 5E. Jurnal Elektronik Pembelajaran Matematika, 300-319. 